\title{
Posthuman Transgression of Boundaries in Octavia Butler's Kindred
}

\author{
MACIEJ CZERNIAKOWSKI \\ John Paul II Catholic University of Lublin, Poland \\ maciej.czerniakowski@kul.pl
}

\begin{abstract}
The present study adopts a critical posthuman perspective to investigate how Octavia Butler's Kindred aims to reconstruct and later dismantle binary oppositions that have been part and parcel of oppressive systems of power such as slavery. Opening his essay with a brief theoretical outline of posthumanism and transhumanism, the author then strives to elaborate on the conceptual framework of the essay and the relevance of the discussion of slavery. Through the main part of the essay, the author focuses on Butler's primary objective, which is to problematise the stereotypical relationship between the enslaved and the enslaver, united by fear and rape, to demonstrate that slavery-in a sense-oppressed them both. The author contends that Butler constructs various borderlands founded on binary oppositions to reveal the arbitrariness of the latter so that a posthuman relational cyborg body can emerge. As the author concludes, this symbiotic body becomes a site of transgression in which all boundaries eventually topple over.
\end{abstract}

Keywords: critical posthumanism; American South; slavery; rape; binary oppositions

\section{INTRODUCTION}

Beyond doubt, the last decade has been witness to the increasing prominence of two strands of research, for example, transhumanism and posthumanism, which have been mistakenly identified, even though their scientific angles may be radically different ${ }^{1}$. Simultaneously, their dynamic development provoked a major controversy among some scientists, e.g. Francis Fukuyama or Jürgen Habermas, who see them as a threat to society. Notwithstanding this profound distrust of posthumanism and transhumanism, both schools seem to announce a new era, which is believed by many to be the next step in the evolution of humankind, though they do it by pursuing different avenues. For instance, Katherine Hayles's theory seems to have originated from her meditations on cybernetics and technology. As she comments, "I understand human and posthuman to be historically specific constructions that emerge from different configurations of embodiment, technology, and culture" (1999, p. 33-34). Crucially, Hayles points to "the liberal subject" as her point of reference and believes that posthumanism begins "when computation rather than possessive individualism is taken as the ground of being, a move that allows the posthuman to be seamlessly articulated with intelligent machines" (1999, p. 33-34). A different approach was adopted by Neil Badmington, who seeks explanation by investigating human fear against alien civilisations in invasion movies. As the critic argues, "[t]he confident humanism of the past seems not to apply at the beginning of the twenty-first century. The line that once absolutely divided and distinguished humans from aliens has become blurred. There is no invasion and, more strikingly, no apparent enemy" (2004, p. 30). Even though Hayles and Badmington come from different angles, they seem to have a similar goal, i.e. revisioning the human being, which has been promoted by numerous other scholars as well.

In this context, all the groundbreaking (thought) experiments aiming at the revision of the human being may give the impression that humanity has already - at least partiallyreached this stage and managed to break with downright oppressive systems that used to plague mankind. What is certainly more vital is that some might safely assume that we have succeeded in producing accurate narratives describing the oppressive systems of power that have 
organised human civilisation for centuries and that these narratives shall serve as a warning for future generations against relapsing into some of its more disgraceful institutions. Unfortunately, this does not seem to be the case as will be shown below, making the discussion of slavery a relevant issue.

\section{CONCEPTUAL FRAMEWORK}

On 3 May 2018, The New York Times published an article commenting on Kanye West's television appearance:

A video of the rapper Kanye West discussing slavery is a sad reminder of America's historical amnesia about the brutal realities of that institution. "When you hear about slavery for 400 years," he said in the clip, which was widely circulated on Twitter, "that sounds like a choice." (Roberts \& Kytle, 2018)

Historically inaccurate and-bearing in mind that West is himself black-utterly incomprehensible, West's statement was widely criticised by the black community and addressed in numerous newspaper articles. As the article in question further comments, an avid Trump supporter, "Mr. West seemed to suggest that enslaved African-Americans were so content that they did not actively resist their bondage, and, as a result, they bear some responsibility for centuries of persecution" (Roberts \& Kytle, 2018). Even though it is perplexing that a black rapper should hold such views, they are disgracefully popular. This puts the questions asked by the narrator of Octavia Butler's "Positive Obsession" into an interesting context.

Towards the end of the story, the narrator asks whether black people benefit from literature, in particular, whether they need science-fiction (Butler, 2005, p. 134-135). In light of Mr. West's comments, any thorough investigation of these questions appears to be superfluous and, even though it has been over 40 years since Bulter's Kindred was first published, the issues addressed by this neo-slave narrative, as well as other texts which were written by Butler, continue to be relevant in the 21st century. Mike Sargeant, a black sciencefiction writer, answers Butler's question saying that "[s]cience-fiction is a great form for black people to make statements about their existence and the history of their existence on the planet" (Francis, 1992). Similar statements appear to be in high demand since, contrary to what Mr. West seems to believe, slavery was not driven by complacency. More likely, it was driven by fear. As Susan Brownmiller observes, African-American slaves were regarded as nothing more than property (1993, p. 62) and therefore they did not enjoy the most basic human rights so often taken for granted in the 21 st century by Western societies.

The morphology of the said fear was skilfully brought into the main theme of Kindred, where everything seems to happen because of and in connection with fear, which travels across space and time as it becomes "bodiless information" (Hayles, 1999, p. 12). As the readers learn at the very beginning of the novel, "Rufus's fear of death calls me to him, and my own fear of death sends me home" (Butler, 1988, p. 50). In this way, fear becomes the driving force of the novel as it draws the two bodies together and pulls them apart, which certainly makes a ripple throughout history by introducing an element of chaos to Antebellum America, but - as Said \& Termizi state - "when chaos happens, it usually conceives something else" (2020, p. 40). It is my contention in this essay to prove that by experiencing fear, excruciating pain, and rape ${ }^{2}$, these two bodies ${ }^{3}$ - one black, the other one white, one female, the other one male - become one postgender body which is neither white nor black, neither female nor male, as these opposites cancel each other out in a rather posthuman fashion and thereby a binary opposition between the enslaver and the enslaved is deconstructed. To quote Donna Haraway, "a potent subjectivity [is] synthesised from fusions of outsider identities..." (1991, p. 66), which leads 
to pulling down a highly oppressive hierarchical system and, as Lisa Long maintains, "nuance[ing] the relationship between history and pain through the trope of rape" (2002, p. 471). Before this issue is addressed, however, let us start at the beginning, i.e. at the end.

\section{DISCUSSION AND ANALYSIS}

\section{ANIMATE VS INANIMATE}

Having lost her left arm, Dana - one of the main protagonists in the novel and its narrator-is slowly recovering in hospital. Kevin - her husband - is being remanded in custody and suspected of a crime that might be regarded as assault and battery on Dana, except there is not a single person who can logically explain what has happened to her. After all, Dana is found with her arm stuck in the wall and even though the police initially detain Kevin, they cannot press charges against him because there is no conclusive evidence proving his guilt. Eventually, the investigation is discontinued since revealing the truth turns out to be beyond anybody's reach. Recalling what he reported to the police, Kevin says,

\footnotetext{
"I told as much of the truth as I could. I said I was in the bedroom when I heard you scream. I ran to the living room to see what was wrong, and I found you struggling to free your arm from what seemed to be a hole in the wall. I went to help you. That was when I realized your arm wasn't just stuck, but that, somehow, it had been crushed right into the wall."

"Not exactly crushed."

"I know. But that seemed to be a good word to use on them - to show my ignorance. It wasn't all that inaccurate either. Then they wanted me to tell them how such a thing could happen. I said I didn't know ... kept telling them I didn't know. And heaven help me, Dana, I don't know."

"Neither do I," I whispered. "Neither do I." (Butler, 1988, p. 11)
}

The ambiguity of the line opening the above quote must not be overlooked. On the one hand, Kevin's inability to uncover the whole truth to the police results from the fact that nobody would be willing to give any credibility to his story if it were recounted in full detail. On the other hand, even though Kevin and Dana did experience the harsh reality of Antebellum America and were not only observers - as Dana meditates, "we were actors. While we waited to go home, we humored the people around us by pretending to be like them" (Butler, 1988, p. 98) - they are invariably flabbergasted by the whole situation. The final episode of Dana's time travel, which ends with Dana's dismemberment and sends her to hospital, cannot be comprehended by the characters on any level, no matter how painful it was for them to live through an outlandish sequence of events that precede the accident. Butler, however, withholds the information regarding what has happened to Dana until the end of the novel, where the narrator accounts of her last journey back home in the following way:

\footnotetext{
Something harder and stronger than Rufus's hand clamped down on my arm, squeezing it, stiffening it, pressing into it - painlessly, at first — melting into it, meshing with it as though somehow my arm were being absorbed into something. Something cold and nonliving.

Something ... paint, plaster, wood - a wall. The wall of my living room. I was back at home - in my own house, in my own time. But I was still caught somehow, joined to the wall as though my arm were growing out of it — or growing into it. (Butler, 1988, pp. 260-261)
}

Even though Dana eventually succeeds in killing Rufus and returns home, the experience of slavery - which she had previously only learnt about from books and television productions - brings about sweeping changes in her psyche and leaves painful scars that will never heal. Not only does the exposure to this tough reality ruin the narrator's psychological and emotional well-being, but also it grossly disfigures her body by leaving her with physical stigma. She loses her body integrity, femininity, and subjectivity, which shall always remind 
her of the impossibility of escaping from the oppressive system of slavery once it has been experienced, simply because - as is repeatedly mentioned in Kindred - the black body is private property that can be disposed of as its owner sees fit.

Certainly, Dana's experience could be extended to the whole black community, whose struggle with the system - essentially invented and developed by whites - has left indelible scars on the whole community. Interestingly, the controversies around Kanye West's statement quoted in the introduction to this essay seem to indicate just this. Neither the black community nor the white one seem to have successfully dealt with their painful pasts that laid the sound foundation for constructing the identity of contemporary American society; making the wall episode even more significant. The blurring of the border between animate and inanimate, i.e. in this case between Dana's body and plaster, happens to be an illustrative example of how slavery crushed human integrity and mutilated generations of innocent people. The scene in question outlines a crushing that turns out to be quite literal. Curiously, the wall which squeezes and stiffens the black body seems to be a perfect, if shocking, illustration of how the black body functioned within the white society of the 19th century. The body, which was objectified and could not escape acts of white cruelty, was step by step dirtied ${ }^{4}$ and dehumanised. After the process of objectification, as a result of which human beings would practically lose their personhood, was completed, torturers had a convenient excuse to eventually rape it. As Susan Brownmiller comments in one of her chapters titled 'A question of Race':

\footnotetext{
The American experience of the slave South, which spanned two centuries, is a perfect study of rape in all its complexities, for the black woman's sexual integrity, was deliberately crushed in order that slavery might profitably endure. (1993, p. 153)
}

Also, the 'profitable' business of slavery to remain so, spared nobody. Therefore, in the context of the whole novel, the loss of an arm by a 26-year-old woman, i.e. mutilating a young female body, seems to be particularly telling and it is surely an 'invitation' to a much more indepth investigation.

\section{BIRTH AND DEMISE OF CYBORG IDENTITY}

Crushing Dana's (sexual) identity by integrating her body with the wall, i.e. creating a chimera-reminiscent of numerous posthuman metamorphoses investigated by, among others, Bruce Clarke - whose sexual identity is thus considerably problematised, influences the readers' perception of the black body on two levels. First of all, it is indicated from the very beginning of the novel that her body, which has just 'fully' completed the process of entering society - as the readers learn in one of the opening scenes, Dana and Kevin have just got married-loses at least some of its subjectivity as a result of the accident and undergoes an objectification process that might impact significantly on Dana's gender stability. Notably, then, a young wife's black body instantly seems to be desexualised and, in a way, sexually impaired since, having lost an arm, it is no longer as attractive as it used to be. Secondly, this objectification appears to be one of the factors that may facilitate rape since withholding part of Dana's body in the past appears to be indicative of the fact that Dana ultimately is Rufus's chattel and shall never escape from him entirely. Quite literally, her body becomes inanimate. It becomes a thing 5 .

At the same time, Rufus does not seem to be a typical slave master and his act should be read in context, which is not to say that it should be excused. On numerous occasions, the man of his times that he unquestionably is, Rufus behaves as though he truly cares for and even loves Dana, who happens to be the spitting image of her several times' grandmother, Alice. The main source of Rufus's feelings towards Dana is that he knows he can rely on her, whereas he cannot count on any support from his parents - his father seems to take great pleasure in 
scolding him, while his mother's hysterical love is more likely to get on his nerves than to console him. Nevertheless, he fails to acknowledge his feelings towards Dana, let alone understand them, and this twisted 'love' eventually pushes him to attempt to rape her. Simultaneously, it appears to be almost inconceivable to advance a hypothesis that Rufus acts as yet another emotionless slave master. Therefore, to further investigate the addressed issues, it would appear indispensable to retrace how he becomes desperate enough to push himself to sexually assault Dana. This will be the focus of the subsequent part of my analysis. For the time being, I wish to point out that it may not be only the black body that is susceptible to being raped in the novel. Unexpected though this statement might be, Rufus's body- the white body - also falls victim to the hierarchical system of the 19th century based on a binary opposition: slave vs enslaver. As the reader learns on numerous occasions, Rufus's body is also "not supposed to have pleasurable feelings" (Morrison, 2007, p. 247) and, quite frankly, its autonomy is repeatedly violated through rape, even if this is not rape in the literal sense of the word. As Sherryl Vint claims,

[i]t is possible to read all Butler's novels as neo-slave narratives since they are all concerned with the continued consequences of slavery, physical and psychological on both slaves and enslavers. They examine questions of labour, violence, and dispossession, asymmetrical relations of dependence, and the need to build liveable futures together with former oppressors. (2007, p. 256)

Kindred details consequences of slavery on enslavers in an outstandingly absorbing fashion. As I noted earlier, Dana's arm is crushed into the wall of her living room because Rufus manages to grab it back in Maryland in the 19th century. Just like the wall, he does not let Dana go. What must be concluded then is that Rufus's hand that gets hold of Dana's arm is transformed in a posthuman flight of fancy into inanimate matter. His hand and the wall are one. This conclusion must be stressed since it shows that it is not only Dana's body that is incorporated into the wall and that is impaired. Rufus's body seems to have suffered the same fate. Curiously, it is already the wall episode that indicates that Rufus's and Dana's bodies become one colourless cyborgian body ${ }^{6}$ which, by being incorporated into inanimate matter, turns into "a potent subjectivity synthesized from fusions of outsider identities and in the complex political-historical layerings" (1991, p. 66). Dana and Rufus become one body that is mercilessly raped by the system of slavery, whose primary objective was to exploit slaves and crush identities, but which backfired and inflicted suffering on the white community as well.

However, beyond dispute, Rufus's body is raped in a much different sense. Although the Rufus who attempts rape on Dana is already a notorious criminal by contemporary standards and there is no denying that he is the only person who must bear the blame, Butler seems to provoke her readers to take a few steps back and reconsider Rufus's motives in a broader context before passing judgment. This might be the reason behind introducing Rufus's younger version to the readers before they learn about the crime which is to end this very peculiar bildungsroman. By giving a detailed description of Rufus's childhood and his transformation into a slave master, Butler makes it impossible for the readers to disregard what Rufus suffered as a child and how these hardships contributed to his evolution. A systematic torturer and a skillful representative of his walk of life, Rufus Weylin used to be a child whose innocence has been crushed all along his growth into an adult man.

The first part of Kindred contains an extended presentation of Rufus's gradual evolution from an innocent boy into a slave master but — so it seems - a slave master with a difference. From the beginning of the story, Rufus is depicted as a rather bright boy who has the unusual, if disconcerting, habit of getting himself into trouble, which most of the time leads him into life-threatening situations. This propensity to put his own life at risk seems to have its origin in the home environment that gives him all the stimuli he needs to destabilise his mental wellbeing and to be transformed into a cold-blooded slave driver. When Dana is called back to the 
American south of the 19th century for the second time, she discovers that Rufus is on the point of burning the whole house down by setting fire to draperies. Under different circumstances, Rufus would be just another kid getting himself into mischief. This scene, however, should be understood simultaneously as Rufus's act of sheer desperation and revenge. As the readers learn, Rufus sets fire in retaliation for being hit by his father, who accused him of stealing his money. Watching how the flames begin to spread, Rufus remembers, though, an incident from the past when he set fire to a barn and therefore he is instantly paralysed with fear:

\footnotetext{
"I started thinking that if I burned the house, he would lose all his money. He ought to lose it. It's all he ever thinks about." Rufus shuddered. "But then I remembered the stable, and the whip he hit me with after I set fire. Mama said if she hadn't stopped him, he would have killed me. I was afraid this time he would kill me, so I wanted to put the fire out. But I couldn't. I didn't know what to do." (Butler, 1988, p. 26)
}

The palpable fear of being killed by his own father, which travels across time and space to snatch Dana from the 20th century, inescapably pushes Rufus's psychological and emotional development in an unexpected direction. Rufus seemingly becomes what the then society expects him to become, i.e. a plantation-running slave owner, but-influenced by his extraordinary experiences from childhood-he is unavoidably driven to question the status quo.

From the introductory chapter onwards, Rufus's experience of fear and pain inflicted by his father problematises the notion of rape and its motives. It becomes clear that they cannot be discussed in terms of a 'traditional' relationship between a victim and a perpetrator since Butler reminds her readers that criminals are made, not born. Whereas one's social background cannot be an excuse for one's crimes, should the said person face justice, it is imperative to state that systems such as American slavery were too complex to be simply broken down into the relations between dominant whites and subjugated blacks. The black body is unquestionably the first that bears fatal consequences of rape, but the white body-which causes this pain - is the one that is raped by an oppressive system, which in theory places this body in a privileged position so that power relations work to its advantage. Instead of benefitting from the status quo, however, the white body-as becomes clear in the case of Rufus - falls prey to its own oppressive mechanisms as it brainwashes and abuses its own offspring.

It is also worth noting that the novel shows how the white mindset is shaped not only by whites but also by black people in what comes to be a self-emergent system of slavery. By indicating this fact, Butler seems to imply that slavery was not based on a simple victimperpetrator relationship but rather on a network of interdependencies that exerted a tremendous impact on people to such an extent that they would spontaneously begin exercising control over each other so that every person could play their role within the system. The novel outlines then how the oppressive system of slavery 'gives birth' to a future rapist, brings him/her up, soils their psyche and physique, and - most crucially — ensures that they shall never 'relapse' into feelings of remorse or compassion. By the time a white person's upbringing has finished, they will have internalised a set of psychological and physical mechanisms that make them perfect members of a "panoptical" (Foucault, 1995, p. 195-196) slave society. Should anybody wish to leave the system, they will be stopped by an inanimate manifestation of the slave machinery, which in the case of Kindred seems to be represented by the wall. How bodies gradually loseor fail to acquire at all - their independence is a recurring motif in the novel and Butler seems to make a point of showing that all bodies - not only black ones - are systematically objectified and dirtied to an extent that they become inanimate objects that are eventually squeezed and crushed by the system. This is how Dana reflects on this issue,

[a]s I hurried up the steps and into the house, I thought of Rufus and his father, of Rufus becoming his father. It would happen some day in at least one way. Someday Rufus would own the plantation. Someday, 
he would be the slaveholder, responsible in his own right for what happened to the people who lived in those half-hidden cabins. The boy was literally growing up as I watched - growing up because I watched and because I helped to keep him safe. I was the worst possible guardian for him - a black to watch over him in a society that considered blacks subhuman, a woman to watch over him in a society that considered women perennial children. (Butler, 1988, p. 68)

Perennial children who were not treated as children by contemporary Western standards anyway and who were raped all the same by domineering white men or, which is even worse, who were implicated by them in crushing other women's cyborg identity. This is precisely what Rufus does to Dana on several occasions. One of them is described by the protagonist in the following passage which outlines Rufus's growing appetite for Alice after she has come back to health following her being recaptured by patrollers:

\footnotetext{
I caught Rufus alone again the next day - in his room this time where we weren't likely to be interrupted. But he wouldn't listen when I brought up the letter. His mind was on Alice. She was stronger now, and his patience with her was gone. I had thought that eventually, he would just rape her again - and again. In fact, I was surprised that he hadn't already done it. I didn't realize that he was planning to involve me in that rape. He was, and he did. (Butler, 1988, p. 162).
}

While Dana's company has shaken the foundations of Rufus's world since their very first encounter on the riverbank and disturbs his evolution into an exemplary slave owner, it is also a crucial factor facilitating Alice's rape and ultimately leading to Rufus's demise. Building a disturbing context, Butler implicates Dana in convincing her grandmother to let Rufus rape her or, otherwise, Dana herself will never be born. This tragic conflict prompts Dana's transformation into a slave and disintegration of her identity as it takes away from Dana what is left of her dignity. Unfortunately for her, however, the dirtying of her body and mind has not finished yet.

On learning that Rufus sold their children south-which is later revealed to be an outright lie-Alice commits suicide, which puts Dana in a perilous situation since she is the spitting image of her grandmother. Alice herself admits at some point that they are "two halves of the same woman" (Butler, 1988, p. 228). After Alice's death, Rufus's mental health deteriorates, which results in Dana and Alice merging into one body in his mind, thereby filling Dana with a new fear that will effectively bring about a blurring of the border between the enslaved and the enslaver and add yet another layering to Dana and Rufus's cyborg identity. As Vint comments,

Rape is the final assault against her sense of herself as a twentieth-century Dana refuses to accept. This is her stand for 'suicide or worse' - she will kill herself or kill Rufus if he crosses this line, a risk she is willing to take even though it is unclear whether she will be able to return to her own time once Rufus is dead. (2007, p. 252)

The scene featuring attempted rape on Dana shows where Rufus's fear eventually led him. His identity disintegrates as he completely loses control of himself and attempts incestuous rape on his granddaughter. At the same time, Dana's fear leads her to kill her grandfather, who is not willing to let her abandon him. In a sense then, both of them are equally abused by the system which dirtied their bodies and minds to the extent that their identity disintegrated and has become a patchwork of other identities that have had a detrimental impact on them. To use Sielke's words, "rape turns into a rhetorical device" $(2002$, p. 2) which helps build a cyborgian, postgender body that literally and symbolically becomes inanimate matter. This is how Butler seems to use posthuman thinking to dismantle the difference between the oppressor and the victim, who both suffer from the system that bred them. 


\section{CYBORG BODY PERFORMING RACISM}

Between her time travels, Dana introduces the readers to the story of how she got married to Kevin and the reactions their decision sparked off among their relatives. Not unexpectedly, both families express their disappointment/hatred since Kevin and Dana are of different skin colour and therefore their relatives deem it unimaginable that they should be a couple. What Butler seems to underscore by outlining a map of American racism is that it is not a problem concerning only the white part of society. Just like Kevin's sister, who is white, says that she wouldn't have Dana in her house because she is black, Dana's uncle says that "he'd rather will them [a couple of apartment houses] to his church than leave them to [her] and see them fall into the white hands" (Butler, 1988, p. 112) should Dana marry Kevin. Undoubtedly, the reasons to be racist and disrespect each other will vary. Among whites, modern-day American racism appears to originate from power relations instilled by slavery, whereas among people of colour it seems to have more to do with retaliation for centuries of subjugation. Regardless of its motivation, though, the racism of 1976 mirrors the racism of Antebellum America, pointing to the fact that little substantial change in the general attitude towards people of colour is visible after over 150 years and - to quote The New York Times article again-it "is a sad reminder of America's historical amnesia about the brutal realities of that institution [slavery]" (Roberts \& Kytle, 2018) - the realities in which Kevin and Dana play the main roles, but they do not seem to excel at it. This is how Dana comments on their 'acting':

And I began to realize why Kevin and I had fitted so easily into this time. We weren't really in. We were observers watching a show. We were watching history happen around us. And we were actors. While we waited to go home, we humored the people around us by pretending to be like them. But we were poor actors. We never really got into our roles. We never forgot we were acting. (Butler, 1988, p. 98)

It is crucial to remember that they were actors who were constantly forced to play the roles foreseen for their respective races both in 1976 and in Antebellum America. Dana seems to address this constant racial oppression when she concludes that "slavery was a slow process of dulling" (Butler, 1988, p. 182) that was supposed to lower and eventually crush resistance to the officially accepted ways of conduct. In 1976, one of the tools used for dulling people into obedience is a lack of social consent for interracial marriage, which-as it is stated above-was frowned upon on both sides of the barricade. On the one hand, Dana's uncle would rather see her marry a black man because he does not want his property to fall into the hands of white people. On the other hand, Kevin sarcastically concludes that his sister's husband "would have made a good Nazi" (Butler, 1988, p. 110). These appalling comments describe what is expected of Dana and Kevin by the American society of 1976 very clearly. The couple is socially banned from marrying the opposite race regardless of their true feelings, which are of much less importance than are agreed with social standards. Nevertheless, they choose to break with these conventions, thereby attempting to redefine their roles. Dana's and Kevin's subjectivity appears to be strong enough for them to ward off the criticism they receive from their 20th-century relatives, but this means going off script' as they refuse to play the roles they are expected to. This unending interplay between the roles they are supposed to perform and those that they choose for themselves points to the fact that male and female bodies - in Scott Bukatman's words - should be "narrated as a site of exploration and transfiguration" (2000, p. 98). Put differently, Dana's and Kevin's bodies invariably take part in a bitter theatrical performance addressing problems of racism and human misery inflicted by white supremacists. Even though they can control their bodies only to a certain extent since there seems to be an invisible puppet master who does that for them, the body becomes the site of a fierce battle between well-established power relations and liberating forces that see humans as subjects, not chattel. In 1976, Kevin and Dana initially win this struggle, fighting the difference between 
white and black in a truly posthuman fashion and abolishing the hierarchical structures of the past. They are, however, put to a much more difficult test when they are both called by Rufus to Antebellum America.

A troubling thought that keeps haunting Dana is whether Antebellum America could turn her into a slave, i.e. an object, as well as whether Kevin could develop a southern mentality and become a slave master. At the beginning of the story, when she meets Rufus for the first time, she can defend her subjectivity and even ask young Rufus to refrain from calling her a 'nigger' (Butler, 1988, p. 24-25). As time passes, her resistance seems to be eroded and reaches a critical point on several occasions. One such situation is when Dana is recaptured by Rufus and his father, which is followed by Tom Weylin whipping Dana after she attempts to escape:

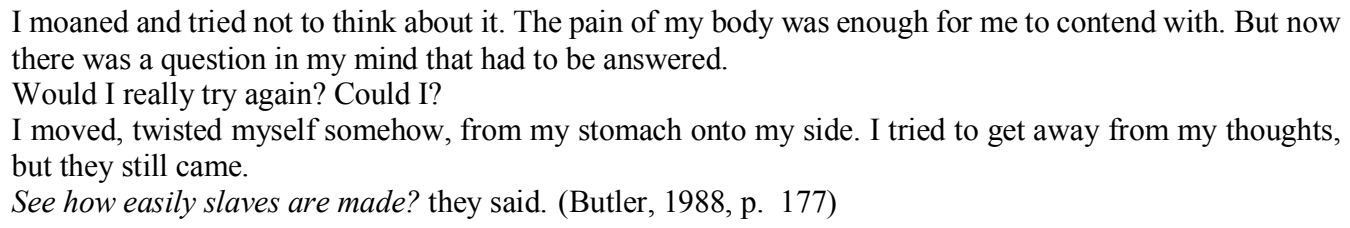

Excruciating physical pain reminds her of her place in 19th-century society and dulls her will to stand against the persecution black people are subjected to. Nevertheless, before she reaches this miserable stage, she manifests repeatedly that her 20th-century subjectivity is outstandingly hard to break, thereby proving that "[g]ender, race, or class consciousness is an achievement forced on us by the terrible historical experience of the contradictory social realities of patriarchy, colonialism, and capitalism" (Haraway, 1991, p. 17). How this achievement is forced on Dana can be observed repeatedly in the novel, but two examples are particularly telling. Interestingly, both cases involve Dana being accused of acting like a white person even though her aunt back in the 20th century regards Dana as being "a little too "highly visible"' (Butler, 1988, p. 111), i.e. 'too black'. Also, both situations are presented one after another as if to reinforce the fact that Dana apparently fails to 'act properly' and therefore she shall not be accepted by Antebellum society.

As for the first case, at one point, Rufus grows tired of how Alice has been ignoring him and asks Dana to help him convince Alice to have sex with him. Dana refuses to do so, but it only angers Rufus, who - in disbelief at being opposed by a black person - is burning with rage: "For several seconds, he stood frozen, towering over me, glaring down as though he meant to hit me ... 'You think you're white!' he muttered. 'You don't know your place any better than a wild animal'" (Butler, 1988, p. 164). It is important to observe that Rufus says Dana considers herself white - regardless of her skin colour-because she dares to stand out against a person she should regard as her master. By doing so, Dana places herself in the network of power relations working to the advantage of white people, which Rufus tries to oppose and treats her as an intruder. By modern standards, she just acts like an independent human being. In the 19th century, though, Dana becomes an out-of-the-ordinary chimera who is both too highly visible because of the blackness of her skin, on the one hand, and the 'whiteness' of her behaviour, on the other. The oxymoronic quality of Dana's existence is underscored by a memory that comes back to Dana minutes before she attempts to talk Alice into having sex with Rufus. Recalling her chat with Alice during which she longingly remembers her husband Isaac, Dana narrates:

Yet moments later for no reason that I could see, she attacked me, "You ought to be ashamed of yourself, whining and crying after some poor white trash of a man, black as you are. You always try to act so white. White nigger, turning against your own people!” (Butler, 1988, p. 165) 
Calling Dana a 'white nigger', Alice unknowingly emphasises how hard it is for Dana to fit in and play her role. Although Dana - being black and acting white - is even more visible in Antebellum America than in the 20th century, she is marginalised by both societies since people appear to be afraid of her. In modern times, she is marginalised by her own family due to her disgraceful marriage to a white man. In the 19th century, she is pushed to the margins since she allegedly acts against her people. Her body is gradually becoming a site for the transgression of boundaries between the two races that blend into one posthuman relational cyborg just the way Melzer describes it in her study:

\footnotetext{
"In most of Butler's stories, female figures fulfil the function of the cyborg in their transgression of boundaries. All of them take up special places in their society and often have experiences in which they are marginalized, and sometimes these experiences make them into powerful agents." (2006, p. 96)
}

Paradoxically, Dana's marginalisation makes her a powerful agent since she successfully safeguards her own birth even though it happens at the price of talking her several times' great grandmother into getting raped. This, in turn, problematises Dana's situation in the 20 th century. As is noted above, her uncle refuses to let his property go into white hands. The problem, though, is that Dana is partially white since white blood-Rufus's blood-flows in her veins as he eventually manages to take advantage of Alice. In this light, it becomes clear that what Alice means as an offence when she calls Dana a white nigger is quite literally the truth. Dana's body is a "cyborg in [her] transgression of boundaries" (Melzer, 2006, p. 96). She is black by her skin colour, but at the same time, she is white because Rufus - her great grandfather - is white. It is important to note that Dana transgresses both bodily and cultural boundaries. Bodily boundaries are transgressed between the two races as she is a greatgrandchild of a white man and a black woman. Cultural boundaries are transgressed since she is considered to act white by Antebellum America, while simultaneously she is treated as an insignificant black other by modern-day society. This, however, does not stop Dana from having a decisive impact on the course of history, which surely would not have happened without her. She might be counted among "[n]onpeople rented for a few hours, a few days, a few weeks" (Butler, 1988, p. 53) by modern-day society, but she eventually turns out to be one of the most crucial agents, whose actions determine the lives of many. This happens when Dana is eventually capable of liberating at least some part of her subjectivity from the 19th-century chains of slavery and securing the status of an independent woman for herself. As Vint observes, "Dana's refusal to accept rape acknowledges that her body is her self. She now better understands how African Americans were made into objects by slavery, and what they lost beyond the brute experience of physical torture." (2007, p. 254)

A truly posthuman relationality between these two bodies and fear which they both feel, mark the beginning and the end of the whole story as if prompting the objectification processand putting it to an end-whose primary goal is inescapably to transgress and abolish an oppressive system. To do this, they have to sacrifice their bodies by putting these at risk. Numerous examples of such perilous situations could be given, but no matter if it is Rufus trying to burn his house down or Dana cutting her wrists so that she can go back home, their bodies are used instrumentally to transgress the boundaries of time and space through an interconnected relational network of people sharing essentially the same emotions and fears even though they are seemingly worlds apart. By building this posthuman relational network, Butler seems to emphasise that at the end of the day all bodies grow into one posthuman body which is susceptible to abuse and should be protected. 


\section{CONCLUSION}

The main goal of the above analysis was to investigate how the notions of racial and class 'difference' are woven into the main theme of Kindred to be deconstructed later. Looking at 'difference' through a magnifying glass and pointing the readers towards a nonsensical nature of the term, Butler brilliantly reveals that the notion just cannot hold. This is chiefly because of a rhizomic network of relations that connect the novel's characters into an inseparable organism on so many levels that seeking neat divisions, which some characters would love to see, is outright preposterous. As Melzer explains, "blurring of boundaries, the growing inability to draw clear distinctions between self and other, is what constitutes the most threatening and fascinating aspect of Butler's alien constructions" (Melzer, 2006, p. 73). Dana, Rufus, and other characters, who essentially become one posthuman, postgender body, exemplify the status quo which Neil Badmington names a "crisis of versus" (123). The crisis that Butler attempts to investigate arises in multiple borderlands: animate/inanimate, white/black skin colour, acting white/acting black, female/male. These dualistic divisions initially help the privileged class construct its hierarchies and power relations, but - as it swiftly turns out - they are nothing but castles in the air and begin to collapse the moment Dana is called to 1815 when she is first connected to her future oppressor through mere human fear. What is created in the aftermath of this revolution is a posthuman metaphor of a relational cyborg body, which also seems to be confirmed by Melzer when she explains that Butler's "main thematic and narrative device is the crossing of boundaries reflected in the conflicting and contradictory figure of Donna Haraway's cyborg, a metaphor for a feminist political identity whose main characteristic is its crossing of culturally defined boundaries" (Melzer, 2006, p. 89). Following up on both Badmington's and Melzer's detailed analyses, I wish to emphasise that "the crossing of boundaries" mentioned by Melzer results in the deconstruction of one of the most oppressive systems in the history of the world and creation of a much more relational environment. By drawing this picture of Antebellum America, Butler means to devise new ways of conduct free from old-fashioned oppressive mechanisms and to construct a new more relational world in which the border between the enslaver and the enslaved becomes blurred in a truly symbiotic relationship, which reminds of Lynn Margulis's words. The critic brilliantly explains that

\footnotetext{
[a]t the base of the creativity of all large familiar forms of life, symbiosis generates novelty. It brings together different life-forms, always for a reason. Often, hunger unites the predator with the prey or the mouth with photosynthetic bacterium or algal victim. Symbiosis brings together unlike individuals to make large, more complex entities. (2001, p. 11-12)
}

Butler meticulously investigates this posthuman symbiosis which proves repeatedly that people - be it oppressors or the oppressed - are mercilessly implicated in situations pushing them to act cruel, to illustrate how the notion of difference can be dismantled. What Butler seems to indicate is that the notion of class and racial difference is an artificial construct that was once created and since then has been harming society. Butler tells her readers, however, that this is all pointless as the oppressive system uses fear that generates only more fear in a spiral of suffering. The solution to this status quo is the embracing of difference, which for many in society seems to be unfathomable. Nevertheless, as Melzer states, "[ $t$ ]he embracing of difference, in which these two mechanisms (deconstruction of existing structures and acceptance of that which is not-I) are combined, makes a clear demarcation of "I" and "notI' (the dualism of "us"' versus "them'") impossible" (2006, p. 69). The very thought of embracing difference turns out to be staggering for many characters in the novel. However, the concept of demarcation that is mentioned by Melzer eventually becomes inapplicable in the speculative world of Kindred. At one point, the boundaries between animate and inanimate, human and inhuman, between white and black are transgressed. Unfortunately for Kevin and 
Dana, their acclimatisation to the harsh reality of slavery is the sine qua non of the "deconstruction of existing structures and acceptance of that which is not-I" (Melzer, 2006, p. 69) to happen. In other words, they need to become part of the system to deconstruct it from within by making all characters blend into one race, which cannot even be called the human race since they blend with the inanimate. They become one 'white nigger' animate/inanimate postgender cyborg body as the enslavers seem to merge with the enslaved. To use Badmington's words, “They're us... We're them" (2004, p. 22).

\section{ENDNOTES}

${ }^{1}$ The present study adopts distinctions between posthumanism and transhumanism introduced by Francesca Ferrando and David Roden.

${ }^{2}$ For a detailed discussion of rape in literature, please refer to Sabine Silke's Reading Rape. The Rhetoric of Sexual Violence in American Literature and Kathleen Walls' The Callisto Myth from Ovid to Atwood. Initiation and Rape in Literature.

${ }^{3}$ Interestingly, Hampton observes that "[t]he body in Butler's fiction is indispensable in understanding how identity is formed and marshaled" (2010, p. xi).

${ }^{4}$ The category of dirtying the black body adopted in this essay is inspired by Patricia Yeager's exhaustive discussion included in her study titled Dirt and Desire. Reconstructing Southern Women's Writing 1930-1990.

${ }^{5}$ It is worth observing that Dana's body can also be referred to as the grotesque body, which "is a body in the act of becoming. It is never finished, never completed; it is continually being built and created; it builds and creates another body..." (Beng at al., 2020, p. 119).

${ }^{6}$ Another interesting approach which could be used to investigate Dana and Rufus's cyborgian body, but which goes beyond the scope of this study, is adopted by Hejaz and Singh to analyse Ian McEwan's Saturday. The critics focus on what they refer to as "a combination of two extremes of Apollonian and Dionysian" (2020, p. 175), whose application could lead to interesting conclusions.

\section{ACKNOWLEDGEMENTS}

My primary debt is to Prof. Zofia Kolbuszewska, whose rigorous intellectual standards have often forced me to revise my scientific ideas. I also owe a great deal to the Beyond Humanism Network. The work was financially supported by The John Paul II Catholic University of Lublin, Poland.

\section{REFERENCES}

Beng, S. J., Termizi, A. A., Talif, R., \& Zainal, Z. I. (2020). Negotiating existential concerns of death and meaninglessness through the grotesque in Oscar Wilde's The Canterville Ghost. 3L: The Southeast Asian Journal of English Language Studies. Vol 26(4), 114 - 126.

Butler, Octavia. (1988). Kindred. Boston: Beacon Press.

Butler, Octavia. (2005). Bloodchild and Other Stories. New York: Seven Stories Press.

Badmington, Neil. (2004). Alien Chic. Posthuman and the Other Within. London and New York: Routledge.

Brownmiller, Susan. (1993). Against Our Will. Men, Women, and Rape. New York: Fawcett Columbine.

Bukatman, Scott. (2000). Postcards from the Postman Solar System. In Badmington, N. (Ed.) Posthumanism (p. 98-111). London: Macmillan Press LTD.

Clarke, Bruce. (2008). Posthuman Metamorphosis: Narrative and Systems. New York: Fordham University Press.

Francis, T. (1992). Black Sci-Fi. Retrieved October 25, 2020 from https://www.youtube.com/ watch? $\mathrm{v}=\mathrm{Cw}$ Sr7ZB9S8.

Ferrando, Francesca. The Posthuman: Philosophical Posthumanism and Its Others. Retrieved February 9, 2021 from https://arcadia.sba.uniroma3.it/bitstream/2307/4356/1/TESI_Ferrando_DEF.pdf.

---. (2013). Posthumanism, Transhumanism, Antihumanism, Metahumanism, and New Materialism. An International Journal of Philosophy, Religion, Politics, and the Arts. Vol. 8(2), 26-32.

Fukuyama, Francis. (2002). Our Posthuman Future. Consequences of the Biotechnology Revolution. New York: Farrar, Straus, and Giroux.

Foucault, Michel. (1995). Discipline and Punish. The Birth of the Prison. New York: Vintage Books.

Habermas, Jürgen. (2003) The Future of Human Nature. Cambridge: Polity Press. 
Hampton, Gregory. (2010). Changing bodies in the fiction of Octavia Butler: slaves, aliens, and vampires. Plymouth: Lexington Books.

Hampton, Gregory. (2006). Kindred: History, Revision, and (Re)memory of Bodies. Obsidian III Literature in the African Diaspora. Vol. 6(2) / Vol. 7(1), 105-117

Haraway, Donna. (1991). Simians, Cyborgs, and Women: The Reinvention of Nature. New York: Routledge.

Hayles, Katherine. (1999). How We Became Posthuman. Chicago and London: The University of Chicago Press.

Hejaz, Neha and Rajni Singh. (2020) The En(Counter) of a Deeper Darkness: Ian McEwan's Saturday. 3L: The Southeast Asian Journal of English Language Studies. Vol. 26(4), 175-185.

Long, Lisa A. (2002). A Relative Pain: The Rape of History in Octavia Butler's Kindred and Phyllis Alesia Perry's Stigmata. College English. Vol. 64(4), 459-483. Retrieved April 28, 2018 from http://www.jstor.org/stable/3250747.

Margulis, Lynn. (2001). The Symbiotic Planet. A New Look at Evolution. London: Basic Books.

Melzer, Patricia. (2006). Alien Constructions. Science Fiction and Feminist Thought. Austin: University of Texas Press.

Morrison, Toni. (2007). Beloved. London: Vintage Books.

Roberts, B \& Kytle, E.J. (2018). The Historian Behind Slavery Apologists Like Kanye West. The New York Times. Retrieved November 1, 2020 from https://www.nytimes.com/2018/05/03/opinion/the-historian-behindslavery-apologists-like-kanye-west.html.

Roden, David. (2015). Posthuman Life. Philosophy at the Edge of the Human. New York: Routledge.

Said, Nur Aainaa Amira Mohd \& Arbaayah Ali Termizi. (2020). Order in Disorder: Exploring Chaos Theory in the Narrative Structure of Chuck Palahniuk's Fight Club. 3L: The Southeast Asian Journal of English Language Studies. Vol. 26(2), 37-49.

Sielke, Sabine. (2002). Reading Rape. The Rhetoric of Sexual Violence in American Literature and Culture, 17901990. Princeton: Princeton UP.

Vint, Sherryl. (2007) "Only by experience": Embodiment and the Limitations of Realism in Neo-Slave Narratives. Science Fiction Studies, Vol. 34, 241-261.

Wall, Kathleen. (1988). The Callisto Myth from Ovid to Atwood. Initiation and Rape in Literature. Kingston and Montreal: McGill-Queen's University Press

Yaeger, Patricia. (2000). Dirt and Desire. Reconstructing Southern Women's Writing 1930-1990. Chicago: The University of Chicago Press. 